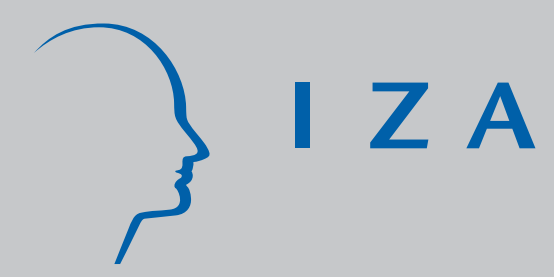

IZADP No. 2621

Innovation and Employment: A Survey

Marco Vivarelli

February 2007 


\title{
Innovation and Employment: A Survey
}

\author{
Marco Vivarelli \\ Università Cattolica Piacenza, CSGR Warwick, \\ Max Planck Institute of Economics Jena and IZA
}
Discussion Paper No. 2621
February 2007

\author{
IZA \\ P.O. Box 7240 \\ 53072 Bonn \\ Germany \\ Phone: +49-228-3894-0 \\ Fax: +49-228-3894-180 \\ E-mail: iza@iza.org
}

\begin{abstract}
Any opinions expressed here are those of the author(s) and not those of the institute. Research disseminated by IZA may include views on policy, but the institute itself takes no institutional policy positions.

The Institute for the Study of Labor (IZA) in Bonn is a local and virtual international research center and a place of communication between science, politics and business. IZA is an independent nonprofit company supported by Deutsche Post World Net. The center is associated with the University of Bonn and offers a stimulating research environment through its research networks, research support, and visitors and doctoral programs. IZA engages in (i) original and internationally competitive research in all fields of labor economics, (ii) development of policy concepts, and (iii) dissemination of research results and concepts to the interested public.
\end{abstract}

IZA Discussion Papers often represent preliminary work and are circulated to encourage discussion. Citation of such a paper should account for its provisional character. A revised version may be available directly from the author. 
IZA Discussion Paper No. 2621

February 2007

\section{ABSTRACT}

\section{Innovation and Employment: A Survey}

According to the "compensation theory", market forces should assure a complete compensation of the initial labour-saving impact of process innovations. In this paper a critique of this approach is proposed through a detailed survey of the theoretical and empirical literature on the subject. The general conclusion is that - although compensation is always working - the complete counter-balancing of dismissed workers cannot be assumed ex-ante.

JEL Classification: J64, O33

Keywords: innovation, technological unemployment, compensation

Corresponding author:

Marco Vivarelli

Facoltà di Economia

Università Cattolica

Via Emilia Parmense 84

I-29100 Piacenza

Italy

E-mail: marco.vivarelli@unicatt.it 


\section{INTRODUCTION}

The diffusion, in the last two decades, of a new "technological paradigm” based on ICTs has implied a new emergence of the old debate about the possible employment consequences of innovation.

Indeed, the fear of technological unemployment has always emerged in ages characterised by radical technological changes. For instance, the striking response of the English workers to the first industrial revolution was the destruction of machines under the charismatic lead of Ned Ludd in the industrial areas and of Captain Swing in the countryside (see Hobsbawm, 1968; Hobsbawm and Rudé, 1969).

On the other hand, since its very beginning, the economic theory has pointed out the existence of economic forces which can compensate for the reduction in employment due to technological progress. Since the classical debate, two views have started to compete in dealing with the employment impact of technological progress: using Ricardo's words, the "working class opinion" was characterised by the fear of being dismissed because of innovation (see Ricardo, 1951, p. 392), whilst the academic and political debate was mainly dominated by a ex-ante confidence in the market compensation of dismissed workers.

Even nowadays - mutatis mutandis - the nature of the different long-term "technological trajectories" can be of paramount importance in explaining national and regional differences in employment and unemployment trends. Obviously, this does not mean that short-term views focusing on prices (wages and interest rates) or on labour market regulation are not important, but they are probably insufficient in providing a complete interpretation of employment evolution.

In this chapter a classical framework (Section 2) will be provided, criticized (Section 3) and used in giving account of the empirical evidence (Section 4). Main findings and conclusions will be discussed in the final Section 5. While this chapter will be mainly devoted to a macroeconomic analysis, the reader interested into the microeconomic aspects of the relationship between innovation and employment can refer to Piva and Vivarelli (2003 and 2004).

\section{THE CLASSICAL“COMPENSATION THEORY”}


The economic discipline - since its foundation and as a part of the heroic attempt to render economics a proper "science" - has tried to dispel all concerns about the possible harmful effects of technological progress, on a basis of a rigorous, counter-intuitive and "scientific theory". Indeed, in the first half of the XIX century economists put forward a theory that Marx later called the "compensation theory" (see Marx, 1961, vol. 1, chap. 13 and 1969, chap. 18). This theory is made up of different market compensation mechanisms which are triggered by technological change itself and which can counterbalance the initial labour-saving impact of process innovation (for an extensive analysis, see also Vivarelli, 1995, chaps.2 and 3; Petit, 1995; Vivarelli and Pianta, 2000, chap. 2; Pianta, 2004).

A) The compensation mechanism "via new machines".

The same process innovations which displace workers in the user industries, create new jobs in the capital sectors where the new machines are produced (see, for instance, Say, 1964, p.87).

B) The compensation mechanism "via decrease in prices".

On the one hand, process innovations involve the displacement of workers; on the other hand, these innovations themselves lead to a decrease in the unit costs of production and - in a competitive market this effect is translated into decreasing prices; in turn, decreasing prices stimulate a new demand for products and so additional production and employment. This mechanism was singled out at the very beginning of the history of the economic thought (Steuart, 1966, vol. II, p.256).

This line of reasoning became the cornerstone of the compensation theory when Say's law became the focus of classical economic theory (see Say, 1964, p.87). In a competitive world, the supply generates its own demand and technological change fully takes part in this self-adjusting process.

The compensation mechanism "via decrease in prices" has been re-proposed many times in the history of economic thought both by neoclassical economists (see Pigou, 1962, p.672) and by modern theorists 
(see Neary, 1981; Stoneman, 1983, chaps. 11 and 12; Hall and Heffernan, 1985; Dobbs, Hill and Waterson, 1987; Nickell and Kong, 1989; Smolny, 1998).

C) The compensation mechanism "via new investments".

In a world where the competitive convergence is not instantaneous, it is observed that during the gap between the decrease in costs - due to technological progress - and the consequent fall in prices, extraprofits may be accumulated by the innovative entrepreneurs. These profits are invested and so new productions and new jobs are created. Originally put forward by Ricardo (1951, vol. I, p.396), this proposition has also been called forth by neo-classicals like Marshall (1961, p.542) and by more recent dynamic models such as those by Hicks (1973), Stoneman (1983, pp. 177-81). The role of lagged innovation in fostering employment evolution is also investigated in Van Reenen (1997) at a microeconomic level.

D) The compensation mechanism "via decrease in wages".

As with other forms of unemployment, the direct effect of labour-saving technologies may be compensated within the labour market. In fact, in a neoclassical framework - with free competition and full substitutability between labour and capital - technological unemployment implies a decrease in wages and this should lead to a reverse shift back to more labour-intensive technologies. The first to apply this kind of argument was Wicksell (1961, p.137), followed by Hicks (1932, p.56) and Pigou (1933, p.256).

In modern times, the wage adjustment is a component of partial equilibrium models such as those by Neary (1981) and Sinclair (1981) and general equilibrium analyses such as those by Layard and Nickell (1985), Venables (1985), Layard, Nickell and Jackman (1991), Davis (1998) and Addison and Teixeira (2001).

E) The compensation mechanism "via increase in incomes". 
Directly in contrast with the previous one, this compensation mechanism has been put forward by the Keynesian and Kaldorian tradition. In a Fordist mode of production, unions take part in the distribution of the fruits of technological progress. So it has to be taken into account that a portion of the cost savings due to innovation can be translated into higher income and hence higher consumption. This increase in demand leads to an increase in employment which may compensate the initial job losses due to process innovations (see Pasinetti, 1981; Boyer, 1988B, 1988C and 1990).

F) The compensation mechanism "via new products".

Technological change is not only process innovation, but it can imply the birth of entirely new economic branches where additional jobs can be created. Once again, the labour-intensive impact of product innovation was underlined by classical economists (Say, 1964, p.88) and even the most severe critic of compensation theory admitted the positive employment benefits which can derive from this kind of technological progress (Marx, 1961, vol. I, p.445).

In the current debate, various studies (Freeman, Clark and Soete, 1982; Freeman and Soete, 1987; Freeman and Soete, 1994; Vivarelli and Pianta, 2000; Edquist, Hommen and McKelvey, 2001) agree that product innovations have a positive impact on employment since they open the way to the development of either entire new goods or main differentiation of mature goods. The "labour-friendly nature” of product innovation turns out to be particularly obvious at the microeconomic level (see, for instance, Entorf and Pohlmeier, 1990; and Brouwer, Kleinknecht and Reijnen, 1993)

\section{A CRITIQUE}

On the one hand, technological change induces market forces which can potentially counterbalance the initial labour- saving effect of process innovation. In addition, a different form of technological progress - namely the diffusion of new products - can have a positive effect on employment trends. 
On the other hand, compensation mechanisms can be hindered by the existence of drawbacks which are often either neglected or mis-specified by the neo-classical conventional wisdom. Using the same taxonomy which has been proposed above, the main criticisms of the compensation theory can be singled out as follows.

A) With few exceptions (see Hicks, 1973), nowadays this compensation mechanism is not put forward anymore. Indeed, Marx's critique of this mechanism was particularly sharp: "...the machine can only be employed profitably, if it...is the (annual) product of far fewer men than it replaces". (Marx, 1969, p.552)

Moreover, labour-saving technologies spread around in the capital goods sector, as well; so this compensation is an endless story which can be only partial (Marx, 1969, p.551).

Finally, the new machines can be implemented either through additional investments (see point C) or simply by substitution of the obsolete ones (scrapping). In the latter case - which is indeed the most frequent one - there is no compensation at all (see, for instance, Freeman, Clark and Soete, 1982).

B) As originally noted by Malthus (1964, vol. II; pp. 551-60), Sismondi (1971, p.284) and Mill (1976, p.97), the very first effect of a labour-saving technology is a decrease in the aggregate demand due to the cancellation of the demand previously associated with the dismissed workers. So, the mechanism "via decrease in prices" deals with a decreased demand and has to more than counterbalance the initial decrease in the aggregate purchasing power.

In addition, this mechanism relies on Say's law and does not take into account that demand constraints might occur. Difficulties concerning the components of the "effective demand" - in Keynes' terms such as a low value of the "marginal efficiency of capital" (see Keynes, 1973, chap. 11) can involve a delay in expenditure decisions and a lower demand elasticity. If such is the case, this compensation mechanism is hindered and technological unemployment ceases to be a temporary problem. 
Finally, the effectiveness of the mechanism "via decrease in prices" depends on the hypothesis of perfect competition. If an oligopolistic regime is dominant, the whole compensation is strongly weakened since cost savings are not necessarily and entirely translated into decreasing prices (see Sylos Labini, 1969, p.160).

C) Also the compensation mechanism "via new investments" relies on the Say's law assumption that the accumulated profits due to innovation are entirely and immediately translated into additional investments. Again, Marx's and Keynes's treatment of Say's law can be used to doubt the full effectiveness of this compensation mechanism. Moreover, the intrinsic nature of the new investments does matter; if these are capital-intensive, compensation can only be partial:

"The accumulation of capital, though originally appearing as its quantitative extension only, is effected, as we have seen, under a progressive qualitative change in its composition, under a constant increase of its constant, at the expense of its variable constituent" (Marx, 1961, vol. I, p.628).

D) Also the mechanism "via decrease in wages" contrasts with the Keynesian theory of effective demand. On the one hand, a decrease in wages can induce firms to hire additional workers, but - on the other hand - the decreased aggregate demand lower employers' business expectations and so they tend to hire less workers.

A second criticism can be launched to this mechanism if the cumulative and irreversible nature of technological change is properly taken into account (see Rosenberg, 1976; Dosi, 1988). In this view, science and technology have their own rules: along a "technological trajectory" a "localised technological progress" occurs. If the cumulative and localised nature of innovation is taken into account, both the hypothesis of perfect substitutability between capital and labour assumed by neoclassical models and the possibility of a reverse in technological change appear to be quite unlikely. 
E) During the "golden age" of the '50s and '60s the Fordist mode of production was based on a relevant change in the labour-wage nexus. Instead of leaving the wage to be regulated by a competitive labourmarket, workers were allowed to take possession of a relevant portion of productivity gains due to technological progress. In turn, the increased real wages involved mass consumption and this stimulated investments leading to further productivity gains through innovation and scale economies (Boyer, 1988A). Labour-saving technologies were introduced on large scale, but the Kaldorian "virtuous circle" allowed an important compensation "via new incomes".

Nowadays, the Fordist mode of production is over for many reasons that cannot be discussed here (see Boyer 1988A and 1990). The distribution of income follows different rules (based more on Phillips' curve than on sharing the productivity gains) and labour markets have returned to be competitive and flexible. On the whole, this compensation mechanism has been strongly weakened in the new institutional contexts (see Appelbaum and Schettkat, 1995).

F) New products are still the more powerful way to counterbalance labour-saving process innovations. Yet, the "welfare effect" (new branches of production) has to be compared with the "substitution effect" (displacement of mature products; see Katsoulacos, 1986). Moreover, different "technological paradigms" are characterised by different clusters of new products which in turn have very different impacts on employment. So, the introduction of the automobile had a much higher labour intensive effect than the diffusion of the home computers. As a matter of fact, in different historical periods and different institutional frameworks, the relative balance between the labour-saving effect of process innovations and the labour-intensive impact of product ones can considerably vary.

A well-balanced conclusion about the compensation theory can be taken from Pasinetti (1981, p.90): "For the time being, we may draw the important conclusion that the structural dynamics of the economic system inevitably tend to generate what has rightly been called technological unemployment. At the same time, the very same structural dynamics produce counter-balancing movements which are capable of bringing macro- economic condition...towards fulfilment, but not automatically". 


\section{EMPIRICAL EVIDENCE.}

The "classical taxonomy" discussed above can also be applied to the present forms of technological change and particularly to the introduction and diffusion of ICTs. Yet, taking into account the discussion in the previous sections, it is obvious that economic theory cannot provide a clear-cut answer about the employment effect of ICTs. Hence, attention should be turned to aggregate, sectoral and microeconomic empirical analyses which should take into account the different forms of innovation, their direct effects on labour, the various compensation mechanisms and the possible hindrances to these mechanisms.

Of course, this is not an easy task. Whilst theoretical economists may develop clear models about the employment impact of process and product innovation, applied economists have "to measure" technological change, the compensation mechanisms and the final employment impact of innovation; from this respect, at least three main problems arise.

First, technological change in general and ICTs diffusion in particular are difficult to measure; traditional indicators such as R\&D (input indicator), patents and crucial innovations (output indicators) are seldom fully available and are often inadequate to fully represent technological change (think - for instance - to the role of tacit knowledge and intangible investments in fostering ICTs diffusion).

Second, as discussed in Section 2, the final employment impact of innovation depends on institutional mechanisms which can be very different at the micro, sectoral and macro levels and can vary in different contexts, such as in different countries or different sectors within the same country.

Third, it is difficult to distinguish the final impact of innovation on employment, since the latter is influenced by many other factors: the macroeconomic and cyclical conditions, the labour market dynamics and regulations, the trends in working time and so on.

In addition to these general shortcomings, there are also problems which arise at each level of analysis. 
Starting from the microeconomic studies, the empirical analysis of the impact of ICTs at the firm's level is extremely useful in revealing the actual ways how new products generate new jobs and labour-saving process innovation destroy old ones. Nevertheless, the main shortcoming of this kind of analysis consists in a "positive bias" which tends to underline the positive employment consequences of innovation. In fact, once the empirical analysis is developed at the level of the single firms, innovative firms tend to be characterised by the better employment performances since they gain market shares because of innovation. Even, when the innovation is labour-saving, these analyses generally show a positive link between technology and employment since they do not take into account the important effect on the rivals, which are crowded out by the innovative firms (the so-called "business stealing" effect, see Van Reenen, 1997; Piva and Vivarelli, 2003). For instance, Greenan and Guellec (2000) using data from French manufacturing sectors over the period 1986-90 - found out a positive relationship between innovation and employment at the firm's level (both product and process innovation). Yet, at the sectoral level, their results confirmed the idea that only product innovation create additional jobs, while process innovation generate jobs within the innovative firm but at the expense of the competitors, leading to an overall negative effect at the sectoral level.

This bias can be corrected when the empirical analysis is carried out at the sectoral level: in this case, a researcher can take into account both the positive performance of innovative firms and the indirect effects on the competitors and so he can investigate the final employment outcome. Yet, also sectoral analyses can be affected by either a negative or a positive bias according to the observation point of view (manufacturing vs services). For instance, Pianta (2000) and Antonucci and Pianta (2002) found an overall negative employment impact of technological change in manufacturing industries across five European countries, while Evangelista (2000) and Evangelista and Savona (2002) found a positive employment relationship in the most innovative and knowledge intensive service sectors and a negative one in the case of financial-related sectors and most traditional services like trade and transports.

Finally, even at the sectoral level, the analysis cannot take into account all the direct and indirect effects of technological change. Only the aggregate macroeconomic studies can jointly assess 1) the labour 
displacement of process innovation in some economic sectors (mainly manufacturing); 2) the compensation effects which operate within those sectors (through decreasing prices and increasing investments) and in other sectors (through intersectoral flows of products and incomes); 3) the positive employment impact of product innovation in other sectors (mainly services). Yet, aggregate empirical analyses are very difficult to put forward because of the three main general problems discussed above. Keeping these methodological remarks in mind, attention will now be focused on empirical contributions at the macroeconomic level, starting from input-output models.

Leontief and Duchin (1986) used input-output matrices to test the employment impact of automation assuming four different scenarios (characterised by different paces of technological change). The authors carried out their simulations taking future demand evolution as exogenous. While all four simulations led to an increasing employment trend, the study revealed a clear labour-saving bias of new technologies: in fact, more accelerated technological progress implied lower employment growth rates. Whitley and Wilson (1982 and 1987) put forward a multisectoral dynamic model explicitly addressed to studying the employment impact of technological change using a compensation framework. In their first study, the two authors forecasted employment levels in 1990 for most sectors of British economy and in their simulation compensation mechanisms were able to more than compensate initial job losses due to process innovation. Among the compensatory forces, the mechanism via decrease in prices resulted the more effective, accounting for more than $50 \%$ of compensation of the initial labour displacement. In their second study, the simulation scenario moved to the period 1985-95 and also took into account office automation and the public sector. In this case, compensation turned out to be only partial with an overall effect of new technologies equal to 288,000 job losses within British economy. At any rate, compensation mechanisms resulted effective in counterbalancing 280,000 initial job losses and most effective mechanisms appeared those "via decrease in prices" and "via new investments".

Very close in spirit to Whitley and Wilson's model, is the framework proposed by Kalmbach and Kurz (1990). Their simulation of the impact of "microelectronic-based best-practice techniques" on the West 
Germany economy showed compensation mechanisms at work, but unable to fully compensate for the initial labour displacement due to ICTs diffusion.

Again about West Germany is the input-output study by Meyer-Krahmer (1992): using data referring to 51 sectors covering the entire economy in the ' 80 s, the author emulated the employment reaction of German economy to innovation (in house R\&D spending and purchased R\&D knowledge - spillovers). His econometric results support the view that technological progress implies overall labour-saving effects; yet important sectoral differences emerge: while purchased R\&D involves job losses in industries like textile, clothing and electronic equipment, in house R\&D stimulates the demand for labour in sectors like chemicals and computer industries.

Departing from input-output models, two other streams of empirical literature can be singled out. On the one hand, some econometric studies within the "compensation approach" (see Section 2) tried to test the validity of (some) compensation mechanisms within a partial or general equilibrium framework. On the other hand, more recent studies turned the attention either to the direct relationship between growth and employment, or to aggregate macroeconomic models.

Sinclair (1981), Layard and Nickell (1985) and Nickell and Kong (1989) belong to the first group of studies. In the first contribution Sinclair put forward a macro IS/LM scheme and concluded that a positive employment compensation can occur if the demand elasticity and the elasticity of factor substitution are sufficiently high. Using estimates based on US data, the author found a strong evidence supporting the mechanism via decrease in wages but not the mechanisms via decrease in prices.

Layard and Nickell (1985) derived a demand for labour in a quasi-general equilibrium framework and stated that the crucial parameter was the elasticity of the demand for labour in response to a variation in the ratio between real wages and labour productivity; in fact, technological change increases labour productivity and - given an adequate elasticity - proportionally the demand for labour and this can be enough to fully compensate initial job losses. Using data for the UK economy, the authors estimated an elasticity coefficient equal to 0.9 and this was sufficient - in the authors' opinion - to rule out innovation from the possible causes of British unemployment. 
Finally Nickell and Kong (1989) focused their attention to the operating of the compensation mechanism "via decrease in prices" in nine UK two-digit industries. Putting forward a price equation where cost-saving effects of labour-saving technologies were fully transferred into decreasing prices, the authors found out that in seven sectors out of nine a sufficiently high demand elasticity was able to imply an overall positive impact of technological change on employment.

Turning the attention to the second stream of literature, according to the different nature of ICTs diffusion (process vs product innovation) and to the different effectiveness of the compensation mechanisms, growth can be more or less labour intensive.

Boltho and Glyn (1995) elaborated data on OECD countries over sub-periods within 1960-93. Their main results from pooling estimates show that the employment/growth relationship is not so robust from a descriptive point of view, but it is confirmed by simple econometric estimates (univariate and contemporaneous). Interestingly enough, the positive correlation between GDP growth and employment growth is also confirmed over the period 1990-1993 at odds with the notion of jobless growth as a result of ICTs diffusion in the OECD economies.

Pini (1996) and Piacentini and Pini (2000) obtained less optimistic results. They carried out estimates of the employment elasticities - both in aggregate and by economic sectors - for the G-6 + Sweden over the period 1960-97. In the '90s, negative elasticities (jobless growth) were found in Italy, Germany, UK and Sweden, while all countries but Japan showed a decrease in such elasticities in comparison with the '80s. Clear-cut findings emerged when the attention was turned to the sectoral analysis: while all the countries showed negative elasticities for manufacturing, they also exhibited positive elasticities in services.

Padalino and Vivarelli (1997) put forward an empirical study on the G-7 economies over the period 1960-1994. Their main conclusions pointed out that: a) In the long run, a marked job creation in North America contrasts with moderate employment creation in Europe; b) while in manufacturing post-Fordism and the diffusion of ICTs technologies mean jobless growth and negative employment elasticities in all countries but Japan, no similar clear-cut evidence is detectable with regard to the 
whole economic system; c) long run evolution has to be distinguished by short run correlation; while North America and Europe structurally differ in their job creation capacity in the long run, both of them keep on showing a strong and statistically significant short run correlation between growth and employment.

Of course, the relationship between growth and employment is only the final outcome of a complex interaction between technological change and employment which operates through many direct and indirect mechanisms, as described in the previous Sections 2 and 3. Vivarelli 1995 (chaps. 7, 8 and 9) and Simonetti, Taylor and Vivarelli (2000) proposed a simultaneous equations macroeconomic model able to jointly take into account the direct labour-saving effect of process innovation, the different compensation mechanisms with their own hindrances and the job-creating impact of product innovation. Running three stages least squares regressions using American, Italian, French and Japanese data over the period 1965-1993, the authors showed that the more effective compensation mechanisms were that "via decrease in prices" and that "via increase in incomes" (especially in European countries till the mid-eighties). The other mechanisms revealed to be less significant and conditional on the institutional structures of the different countries; for instance the "mechanism via decrease in wages" turned out to be relevant in the American flexible labour market. Finally, product innovation significantly revealed its labour intensive potentiality only in the technological leader country in the period, namely the US.

\section{CONCLUSIONS}

1) According to the "compensation theory", market forces should assure a complete compensation of the initial labour-saving impact of process innovations. In Section 3 a critique of this approach has been proposed, the general conclusion being that - although compensation is always working - the complete counter-balancing of dismissed workers cannot be assumed ex-ante. 
2) Given this theoretical indefiniteness, the risk is that the debate on the employment consequences of technological change degenerates into a stalemate or into an ideological quarrel. One possible way-out from this situation is to carry-out empirical works which try to assess whether or not the demand of labour is affected by innovation.

3) As far as the available empirical evidence is concerned, contrasting results can emerge according to the different levels of analysis. While most of microeconometric studies find out a positive correlation between ICTs and employment, some doubts can be raised about the generalizability of such micro studies. Once attention is turned to the sectoral level, the distinction between product innovation (in labour friendly growing sectors, such as new ICT related services) and process innovation (in laboursaving restructuring sectors, mostly in manufacturing) becomes important. At the aggregate level, different input-output simulations can have opposite results according to the functioning of different "within and between sectors" compensation mechanisms. Finally, contrasting empirical results - about the occurrence of jobless growth in different periods and different countries - are the outcome of different balances between product and process innovation and different degrees of effectiveness of compensation mechanisms.

4) On the whole, economists cannot propose a clear-cut diagnosis about the employment impact of innovation, either theoretically or empirically. A pragmatic approach should be put forward: the relationship between technological change and employment is a complex problem which cannot be entirely solved by partial equilibrium models or apodictical hypotheses or unfounded empirical generalizations. Indeed, it is necessary to start from an "open minded" theoretical approach and from reliable data and then try to patiently discover, represent and estimate all the various direct and indirect effects of technological change. 


\section{REFERENCES}

Addison J. and Teixeira, P. 2001. Technology, Employment and Wages, Labour, 15, 191-219

Antonucci, T. and Pianta, M. 2002. Employment Effects of Product and Process Innovation in Europe, International Review of Applied Economics, 16, 295-307

Appelbaum, E. and Schettkat, R. 1995. Emplyment and Productivity in Industrialized Economies, International Labour Review, 134, 605-23

Boltho, A. and Glyn, A. 1995. Can Macroeconomic Policies Raise Employment?, International Labour Review, 134, 451-70

Boyer, R. 1988A. Technical Change and the Theory of Régulation, in Dosi, G., Freeman, C., Nelson, R., Silverberg, G. and Soete, L. (eds), Technical Change and the Economic Theory, London, Pinter, 67-94 Boyer, R. 1988B. New Technologies and Employment in the 1980s: From Science and Technology to Macroeconomic Modelling, in Kregel, J.A., Matzner, E. and Roncaglia, A. (eds), Barriers to Full Employment, London, Macmillan, 233-68

Boyer, R. 1988C. Assessing the Impact of RD on Employment: Puzzle or Consensus?, paper presented at the International Conference on New Technology: its Impacts on Labour Markets and the Employment System, Berlin, December 5-7

Boyer, R. 1990. The Capital Labor Relations in OECD Countries: from the Fordist "Golden Age" to Contrasted National Trajectories, working paper CEPREMAP n.9020, Paris

Brouwer, E., Kleinknecht, A. and Reijnen, J.O.N. 1993. Employment Growth and Innovation at the Firm Level: An Empirical Study, Journal of Evolutionary Economics, 3, 153-59

Davis, D.R. 1998, Technology, Unemployment, and Relative Wages in a Global Economy, European Economic Review, 42, 1613-33.

Dobbs, I.M., Hill, M.B. and Waterson, M. 1987. Industrial Structure and the Employment Consequences of Technical Change, Oxford Economic Papers, 39, 552-67 
Dosi, G. 1988. Source, Procedure and Microeconomic Effects of Innovation, Journal of Economic Literature, 26, 1120- 71

Edquist, C., Hommen, L. and McKelvey, M. 2001. Innovation and Employment: Product Versus Process Innovation, Cheltenham, Elgar.

Entorf, H. and Pohlmeier, W. 1990. Employment, Innovation and Export Activities J.P. Florens (ed.), Microeconometrics: Surveys and applications, London, Basil Blackwell

Evangelista, R. 2000. Innovation and Employment in Services, in Vivarelli, M. and Pianta, M. 2000 (eds). The Employment Impact of Innovation: Evidence and Policy, London, Routledge, 121-48

Evangelista, R. and Savona, M. 2002. The Impact of Innovation on Employment in Services: Evidence from Italy, International Review of Applied Economics, 16, 309-18

Freeman, C., Clark, J. and Soete, L. 1982. Unemployment and Technical Innovation, London Pinter Freeman, C. and Soete, L. (eds) 1987. Technical Change and Full Employment, Oxford, Basil Blackwell Freeman, C. and Soete, L. 1994. Work for All or Mass Unemployment? Computerised Technical Change into the Twenty-first Century, London-New York, Pinter

Greenan, N. and Guellec, D. 2000. Technological Innovation and Employment Reallocation, Labour, $14,547-90$

Hall, P.H. and Heffernan, S.A. 1985. More on the Employment Effects of Innovation, Journal of Development Economics, 17, 151-62

Hicks, J.R. 1932. The Theory of Wages, London, Macmillan

Hicks, J.R. 1973. Capital and Time, Oxford, Oxford University Press

Hobsbawm, E.J. 1968. Industry and Empire: An Economic History of Britain since 1750, Harmondsworth Middlesex, Penguin Books

Hobsbawm, E.J. and Rudé, G. 1969. Captain Swing, London

Kalmbach, P. and Kurz, H.D. 1990. Micro-electronics and Employment: A Dynamic Input-output Study of the West-German Economy, Structural Change and Economic Dynamics, 1, 371-86

Katsoulacos, Y.S. 1986. The Employment Effect of Technical Change, Brighton, Wheatsheaf 
Keynes, J.M. 1973. The General Theory of Employment, Interest and Money, in The Collected Writings of John Maynard Keynes, London, Macmillan, first edn 1936

Layard, R. and Nickell, S. 1985. The Causes of British Unemployment, National Institute Economic Review, 111, 62-85

Layard, R., Nickell, S. and Jackman, R. 1991. Unemployment: Macroeconomic Performance and the Labour Market, Oxford, Oxford University Press

Leontief, W. and Duchin, F. 1986. The Future Impact of Automation on Workers, Oxford, Oxford University Press

Malthus, T.R. 1964. Principles of Political Economy, New York, M. Kelley, first edn 1836

Marshall, A. 1961. Principles of Economics, Cambridge, Macmillan, first edn 1890

Marx, K. 1961. Capital, Moscow, Foreign Languages Publishing House, first edn 1867

Marx, K. 1969. Theories of Surplus Value, London, Lawrence \& Wishart, first edn. 1905-10

Meyer-Krahmer F. 1992, The Effects of New Technologies on Employment, Economics of Innovation and New Technology, 2, 131-49

Mill, J.S. 1976. Principles of Political Economy, New York, M. Kelley, first edn 1848

Neary, J.P. 1981. On the Short-run Effects of Technological Progress, Oxford Economic Papers, 32, 224-33

Nickell, S. and Kong, P. 1989. Technical Progress and Jobs, Centre for Labour Economics, Discussion Paper n.366, London, London School of Economics

Padalino. S. and Vivarelli, M. 1997. The Employment Intensity of Economic Growth in the G-7 Countries, International Labour Review, 136, 191-213

Pasinetti, L. 1981. Structural Change and Economic Growth, Cambridge, Cambridge University Press Petit, P. 1995. Employment and Technological Change, in Stoneman, P. (ed.), Handbook of the Economics of Innovation and Technological Change, Amsterdam, North Holland, 366-408 
Pianta, M. 2000. The Employment Impact of Product and Process Innovations, in Vivarelli, M. and

Pianta, M. 2000 (eds). The Employment Impact of Innovation: Evidence and Policy, London, Routledge, 77-95

Pianta, M. 2004. Innovation and Employment, in Fagerberg, J., Mowery, D. and Nelson, R. (eds), The Oxford Handbook of Innovation, Oxford University Press, Oxford, chap. 21.

Piacentini, P. and Pini, P. 2000. Growth and Employment, in Vivarelli, M. and Pianta, M. 2000 (eds). The Employment Impact of Innovation: Evidence and Policy, London, Routledge, 44-76

Pigou, A. 1933. The Theory of Unemployment, London, Macmillan

Pigou, A. 1962. The Economics of Welfare, London, Macmillan, first edn 1920

Pini, P. 1996, An Integrated Cumulative Growth Model: Empirical Evidence for Nine OECD countries, 1960-1990, Labour, 10, 93-150

Piva, M. - Vivarelli, M. 2003. Innovation and Employment: Evidence from Italian Microdata, IZA Discussion Paper n. 730, Bonn.

Piva, M. - Vivarelli, M. 2004. Technological Change and Employment: Some Micro Evidence from Italy, Applied Economics Letters, 11, 373-76

Ricardo, D. 1951 Principles of Political Economy, in Sraffa, P. (ed.), The Works and Correspondence of David Ricardo, Cambridge, Cambridge University Press, vol. 1, third edn 1821

Rosenberg, N. 1976. Perspectives on Technology, Cambridge, Cambridge University Press

Say, J.B. 1964. A Treatise on Political Economy or the Production, Distribution and Consumption of Wealth, New York, M. Kelley, first edn 1803

Simonetti, R., Taylor, K. and Vivarelli, M. 2000. Modelling the Employment Impact of Innovation, in Vivarelli, M. and Pianta, M. (eds), The Employment Impact of Innovation: Evidence and Policy, London, Routledge, 26-43

Sinclair, P.J.N. 1981. When will Technical Progress Destroy Jobs?, Oxford Economic Papers, 31, 1-18 Sismondi, J.C.L. 1971. Nouveaux Principes d'Economie Politique ou de la Richesse dans ses Rapports avec la Population, Paris, Calmann- Levy, first edn 1819 
Smolny, W. 1998. Innovations, Prices and Employment: A Theoretical Model and an Empirical Application for West German Manufacturing Firms, Journal of Industrial Economics, 46, 359-81

Steuart, J. 1966. An Inquiry into the Principles of Political Economy, Chicago, Oliver and Boyd, first edn 1767

Stoneman, P. 1983. The Economic Analysis of Technological Change, Oxford, Oxford University Press Sylos Labini, P. 1969. Oligopoly and Technical Progress, Cambridge (Mass.), Harvard University Press, first edn 1956

Van Reenen, J. 1997. Employment and Technological Innovation: Evidence from U.K. Manufacturing Firms, Journal of Labor Economics, 15, 255-84

Venables, A.J. 1985. The Economic Implications of a Discrete Technical Change, Oxford Economic Papers, 37, 230-48

Vivarelli, M. 1995. The Economics of Technology and Employment: Theory and Empirical Evidence, Aldershot, Elgar

Vivarelli, M. and Pianta, M. 2000 (eds). The Employment Impact of Innovation: Evidence and Policy, London, Routledge

Whitley, J.D. and Wilson, R.A. 1982. Quantifying the Employment Effects of Micro-electronics, Futures, 14, 486-95

Whitley, J.D. and Wilson, R.A. 1987. Quantifying the Impact of Information Technology on Employment Using a Macroeconomic Model of the United Kingdom Economy, in OECD, ICCP paper 12: Information Technology and Economic Prospects, OECD, Paris Wicksell, K. 1961. Lectures on Political Economy, London, Routledge \& Kegan, first edn 1901-1906 